\title{
Work-related factors as predictors in the retirement decision-making process of older workers in the Netherlands
}

\author{
Author 1 \\ Hanna van Solinge. \\ Netherlands Interdisciplinary Demographic Institute (NIDI), PO Box 11650, 2502 AR The \\ Hague, The Netherlands, E-mail: solinge@ nidi.nl
}

\section{Author 2}

Kène Henkens.

Netherlands Interdisciplinary Demographic Institute (NIDI), PO Box 11650, 2502 AR The Hague and University of Amsterdam, Department of Sociology, The Netherlands Email:Henkens@nidi.nl

\begin{abstract}
This article examines work-related factors and their impact on the retirement decision-making process. We particularly focus organizational HR-policies and normative climate regarding retirement. Organizations create opportunities and conditions for career extension via their personnel instruments. The normative climate may encourage or discourage retirement. We use a 10-year follow-up study among 1,458 older employees in the Netherlands aged 50-59 at baseline. Results reveal that older workers are sensitive to social approval earned from their coworkers and supervisor. A social climate that supports working up to higher ages is an important requisite for reducing the attractiveness of the early retirement option. Retirement intentions, formed in the years prior to retirement, are shaped by workplace norms and supervisors' attitudes. Results indicate that in order to delay retirement, policy initiatives cannot be reduced to altering financial restrictions surrounding retirement but need to address the forces at the organizational level that channel workers out of employment.
\end{abstract}

Key words: retirement intention, retirement timing, organizational context, normative context, supervisor support 


\title{
Work-related factors as predictors in the retirement decision-making process of older workers in the Netherlands
}

\begin{abstract}
This article examines work-related factors and their impact on the retirement decision-making process. We particularly focus organizational HR-policies and normative climate regarding retirement. Organizations create opportunities and conditions for career extension via their personnel instruments. The normative climate may encourage or discourage retirement. We use a 10-year follow-up study among 1,458 older employees in the Netherlands aged 50-59 at baseline. Results reveal that older workers are sensitive to social approval earned from their coworkers and supervisor. A social climate that supports working up to higher ages is an important requisite for reducing the attractiveness of the early retirement option. Retirement intentions, formed in the years prior to retirement, are shaped by workplace norms and supervisors' attitudes. Results indicate that in order to delay retirement, policy initiatives cannot be reduced to altering financial restrictions surrounding retirement but need to address the forces at the organizational level that channel workers out of employment.
\end{abstract}

Key words: retirement intention, retirement timing, organizational context, normative context, supervisor support 


\section{Introduction}

Without exception, all Western countries face the aging of their population. In 2011 the first post-war baby boomers reached retirement age, foretelling a rapid growth of the retired population. Extending people's working life is seen as a key element in dampening or curtailing the rising costs associated with an ageing population. Most governments have adopted longerwork policies and have implemented pension reforms that limit opportunities for an early exit from the workforce. In the Netherlands, for example, all facilities (including tax incentives) to stop working before age 65 were abolished in 2006, and the age at which people are eligible for a public pension will be increased gradually to age 67 by 2025 . As a result of these reforms, the financial opportunity structure for an early exit from the labour force will become much more restrictive in coming decades. Retirement decisions of older workers are not only determined by financial considerations though. A host of other factors at home and at work play a role too. Both within the household and within their labour organization, older workers may face forces that increase or decrease their propensity to remain in the labour force.

The notion that the household or work context of older workers affects decision-making around retirement is not new (Szinovacz 2003, Moen 1996, Beehr and Bennett 2007). Previous research of Henkens (1999), for example, clearly shows that early retirement is motivated not only by financial or health considerations but also by a lack of spousal support to remain in the workforce. Many studies have investigated the association between work and job characteristics (e.g., experienced work pressure, challenge and growth opportunities) and retirement plans and/or behaviour of older workers (see for example: Blekesaune and Solem 2005, Schreurs, Van Emmerik, De Cuyper, Notelaers and De Witte 2010). 
Much less attention is paid in the literature to the broader organizational context. This is remarkable, given the fact that it is precisely at this level that opportunities and constraints for career extension are shaped (Vickerstaff, John, Cox and Keen 2004). Research among European employers shows that they tend to be scantly committed to encouraging their older workers to remain active in the labour force (Conen, Henkens and Schippers 2011, Conen, Van Dalen and Henkens 2009). As a result, organizational policies supporting longer working lives are not very well developed yet.

This article particularly focuses on the role of organizations in the retirement decisionmaking process of older workers. We distinguish between two dimensions of the organizational context that are deemed of interest: organizational HR policies regarding older workers and organizations' normative climate regarding retirement. The underlying assumption is that organizations create opportunities and conditions for career extension via their personnel instruments (e.g. customizing work or working times, retaining knowledge). The normative climate refers to the social context of work and the extent to which this context encourages or discourages retirement.

The objective of this study is to advance the existing literature on retirement decisionmaking and the factors that contribute to older workers' propensity to continue working. Although this article focuses on organizational policies and practices, decision-making about retirement cannot be studied in isolation of the financial context that facilitates or restricts retirement. We also acknowledge that characteristics of older workers' jobs (e.g. heavy or light) affect the decision as to whether or not to stop working.

The study is based on data from the NIDI Work and Retirement Panel, an on-going longitudinal survey of older workers (50 years and over) of three private-sector organizations and among civil 
servants in the Netherlands. We examined a subset of 1,461 individuals who were aged 50-59 and in a career job at the time of the first interview in 2001 and who participated in at least two of the three study waves undertaken in 2006 and 2011. The panel nature of the research allowed us to examine two aspects of the retirement decision-making process. In addition to the planned retirement age (also known as retirement intention), which was asked in 2001 to all participants, the study also provides insight into actual retirement age. Observed retirement behaviour may however differ considerably from retirement intentions (Anderson, Burkhauser and Quinn 1986, Henkens and Tazelaar 1997, Prothero and Beach 1984), and these discrepancies may point to circumstances that place restrictions on the realization of work-retirement intentions. Many older workers stop working earlier than initially anticipated, and this is not always voluntary (Van Solinge and Henkens 2007, Szinovacz and Davey 2005). This suggests that the factors that play a role in the formation of pension plans may differ from the forces that guide actual retirement.

\section{Theoretical background}

There is a rich history of research on the retirement decision-making process. The subject has been studied from a variety of scientific disciplines, such as economics, sociology and psychology. Most theories about retirement decision-making implicitly or explicitly employ a cost-benefit framework, assuming that individuals choose to retire once the benefits of retirement exceed those of working (Feldman and Beehr 2011). The particular factors that are assumed to play a role in the cost-benefit considerations do vary by discipline. In this study we integrate insights from economic and sociological research on retirement decision-making with insights from organizational psychology. 
The key assumption underlying micro-economic research is that individual retirement decisions are governed by income/leisure considerations. Retirement is seen as a decision regarding the optimal age to stop working given the individual's environment and relative preference for income and leisure (Leonesio 1996). Financial incentives, particularly expected retirement income or replacement rates ${ }^{\mathrm{i}}$ are deemed to influence retirement choices (Gruber and Wise 2004). Older workers' own pension entitlements are however just one aspect in the financial retirement context. Other relevant financial factors are spousal (retirement) income and wealth and property. Non-economic factors, particularly health, are deemed to influence income/leisure choices too. Poor health is assumed to increase the preference for leisure (Gustman and Steinmeier 2009).

The economic literature tends to ignore the social context of retirement decisions. This is in contrast with much of the more recent sociological literature, which emphasizes the contextual embeddedness of the retirement decision-making process. This literature stresses that attitudes and decisions about retirement are not formed in a social vacuum but evolve from a variety of contextual influences at the household, organizational and societal levels (Szinovacz 2003, Moen 1996, Beehr and Bennett 2007). The family is an important life sphere that interacts with employment (Szinovacz, 2003). There is a growing recognition of the important role of the household, the partner in particular, in the retirement decision making process (e.g., Henkens \& Van Solinge, 2002). One of the main discontinuities associated with full retirement is the lack of social interaction with others. For married older workers, social interaction with the spouse can at least partially substitute for continued interaction with colleagues; for unmarried workers staying in the career job is likely to be more critical in maintaining social contacts with others. The partner's work status may play a role as well, in the sense that non-working partners may 
stimulate (early) retirement. Likewise, the economic literature so far has paid little attention to job and organizational factors (such as HR policies) and their impact on the work/retirement considerations of older workers (Shultz and Wang 2011). We assume that retirement decisions are influenced by older workers' financial context and health, and their work context. How the various work-related factors are assumed to impact work/retirement positions is elaborated below.

\section{Work /job characteristics}

Discontent with one's work and working environment reinforces a worker's propensity to withdraw from the workplace (Estryn-Behar, Van der Heijden, Fry and Hasselhorn 2010, Adams and Beehr 1998). The literature suggests that intrinsic work values have gained importance in recent decades (e.g., Twenge, Campbell, Hoffman and Lance 2010). For example, a Dutch study revealed that employees favoured immaterial aspects of their jobs (aspects that allow for selfexpression such as job variety and autonomy, and challenge) over material aspects (e.g., salary). Only for a small minority of employees did work have a merely instrumental value, that is, no other benefits than money (Van Hoof 2002).

In this study we examine the impact of job characteristics on retirement decision-making. We consider two aspects of job characteristics, relating to the extent to which work is experienced either as a burden or as a challenge. Bakker et al. (2001) make a similar distinction between "job demands" and "job resources" in their Job Demands Resources (JD-R) model. Demands refer to aspects of the job that require sustained physical and/or psychological effort and are therefore

associated with physiological and/or psychological costs. These demands are negative aspects of the job and include burdens such as overload and job pressure. Job resources or rewards, on the 
other hand, are positive aspects of the job that keep people healthy and motivated and contribute to personal development and growth (Bakker and Demerouti 2007). Rewards include such characteristics as challenges, autonomy and job control. The JD-R model posits that job demands and job resources initiate two different psychological processes, which eventually affect important organizational outcomes. In the first place there is the health impairment process. Through this process, poorly designed jobs or chronic job demands exhaust employees' mental and physical resources. This might lead to a depletion of energy and health problems, and eventually dropping off from work. In the second place there is the motivational process, through which job resources exert their motivating potential and lead to high work engagement, low cynicism, excellent performance and low turnover intentions. Schreurs et al. (2010) and Henkens and Leenders (2010) have applied this model to retirement research. They found a negative association between "job demands" and retirement intentions (workers with high job demands preferred an earlier exit from the labour force). Job resources are assumed to have the opposite effect (see also: Kubicek, Korunka, Hoonakker and Raymo 2010). We include five job characteristics in our model. Three of these — physically demanding work, irregular work/shift work and perceived job pressure — are hypothesized to be unfavourable or demanding job attributes. The other attributes — perceived job challenge and perceived growth opportunities are assumed to be favourable or rewarding.

Hypothesis 1a: Demanding job characteristics — physically demanding work, irregular work/shift work and job pressure — are associated with lower (planned) retirement ages.

Hypothesis 1b: Rewarding job characteristics — job challenge and growth opportunities — are associated with higher (planned) retirement ages. 


\section{Organizational policies}

Organizational policies influence the way employees operate in organizations. Human resource policies are deemed to serve an organization's strategic goal in terms of maintaining a good personnel structure, achieving an optimal combination of skills and knowledge, and keeping labour costs acceptable (Van der Heijden, Schalk and Van Veldhoven 2008). In recent decades, age-related HR policies within organizations have strongly focused on facilitating early retirement as a strategy to cope with the contingencies of the labour market. Within HR practices a distinction can be made between general HR instruments and age-related personnel instruments. The first type involves investments in human capital such as training and schooling opportunities, and job mobility activities as well as work-life balance arrangements that target all employees, not just older workers. The second type involves instruments that particularly match the needs of older workers. We include three types of HR instruments in our model to predict retirement decisions. Two of these (training and schooling, and flexible working opportunities) are general instruments, the other (phased or partial retirement) is age-related. We assume that both types of instruments contribute to extending the working lives of older adults.

Stimulating training and lifelong learning is generally regarded as an investment in an organization's human capital (Becker 1975, Thurow 1975). Training not only enhances the employability of individual workers, it also has a positive effect on organizational commitment (Taylor and Walker 1998, Armstrong Stassen and Ursel 2009). In practice, however, organizations tend to invest less in training older workers than their younger peers. The underlying assumption is that an investment in older workers will not pay, since they are close to their retirement date (Taylor and Urwin 2001, Taylor, Brooke and di Biase 2010). So far, there is little research examining the impact of schooling and training on retirement decisions. Available 
studies do suggest that older adults who get the opportunity to learn new skills intend to stay longer with their companies (e.g., Armstrong Stassen and Ursel 2009, Herrbach, Mignonac, Vandenberghe and Negrini 2009). In this article we study the effect of perceived training opportunities on retirement decisions and hypothesize that:

Hypothesis 2: Older workers who perceive greater access to training and schooling opportunities have higher (planned) retirement ages.

When older workers are consulted about the conditions under which they would like to continue working longer, flexible working arrangements, opportunities for part-time work and extra leave are rated high (e.g, Phillipson 2004, Patrickson 2003, Van Loo, De Grip and Montziaan 2006). Hedge, Borman and Lammlein (2006) noted that older employees often want to continue working, but on different terms that include more flexible work arrangements and reduced hours. In recent years, work-life balance initiatives have been developed by industrial countries around the world. Initiatives to give workers more control over their working time, such as the Netherlands' Adjustment of Hours Law and Denmark's amendments to the Act on Part-time Work, assist workers in improving their work-life balance, e.g. by allowing them to devote more time to caregiving and to pursue other interests outside of work. The underlying assumption is that work-life balance arrangements help reduce stress in the workplace. This can lead to a more motivated and loyal workforce, increased productivity, reduced absenteeism and less early retirement. Relatively little research has examined the effects of such arrangements on pension decisions, and the available evidence is ambiguous. Stassen \& Ursel (2009: US) and Herrbach et al. (2009: France), for example, did not find a significant association between opportunities for flexible work in terms of time and place and actual or planned retirement age. This is in contrast 
with Bal, De Jong, Jansen and Bakker (2011: Netherlands), although it should be noted that, with an average age of 42 years, their sample is significantly younger. We examine the impact of flexible work arrangements using a compound measure reflecting the degree of flexibility in work (see also Table 1). We assume the following:

Hypothesis 3: Older workers who have more opportunities to work flexibly in terms of time and place have higher scheduled or planned retirement ages.

Many collective labour agreements in the Netherlands include phased (or partial) arrangements. The basic idea behind phased retirement is that a worker remains with his employer while gradually reducing working hours and effort. It is generally assumed that this can not only provide a more satisfying path to full retirement, but can also preserve specific human capital and thereby enhance productivity (Hutchens and Grace-Martin 2006). Not much is known, however, about whether and how these arrangements affect attitudes and behaviour of older employees. Research on the effectiveness of phased retirement arrangements as a tool for postponing retirement age is limited (Greller and Stroh 2003) and not univocal. For example, a study by Ghent, Allen and Clark (2001) among faculty members in 15 campuses of the University of North Carolina revealed that persons choosing the phased retirement option would have likely remained working full-time at their universities had the phased retirement option not been available. We look at whether using the option of part-time retirement in the years before a worker is eligible for full-time retirement reduces the propensity for full-time retirement. Although the expected effects of these arrangements on retirement are not systematically supported in the empirical literature, we assume the following: 
Hypothesis 4: Older workers who make use of phased retirement arrangements have higher (planned) retirement ages.

\section{Workplace norms}

In this study, we examine the impact of organizations' workplace norms and attitudes regarding retirement along two lines: older workers' perception of the organization's customs and practices regarding retirement timing and supervisors' support for extending working life, as perceived by the older workers.

Life transitions, including retirement, are subject to social norms about appropriate timing. Age norms are woven into the fabric of many social institutions in both formal and informal ways (Settersten 1998). Formal age norms are codified in diverse laws and rules; norms about the "right time" to retire are formally expressed in age boundaries established by public and private pension schemes. Scholars suppose that informal age norms, defined as shared judgments or expectations regarding age-appropriate behaviour, exert significant influence on the behaviour of group members (Settersten and Hagestad 1996). Like other social groups, work organizations have shared expectations about ages at which particular transitions ought to occur (Lawrence 1996). Organizational or workplace norms regarding retirement will signal older employees when they should move out of the workplace (e.g., Feldman and Beehr 2011, Van Dam, Van der Vorst and Van der Heijden 2009, Potocnik, Tordera and Peiró 2009). Lawrence (1996) has argued that even in the absence of explicit age norms, a person's age relative to the organizational age distribution may influence individual decisions. Age distribution constitutes an implicit timetable, and there is evidence that people use their perceptions of this timetable to assess whether their careers are on or off schedule (see also: McCann and Giles 2003). In this article, workplace norms regarding retirement are identified by examining the retirement of older 
workers' peers in the organization. We posit that organizational customs with respect to retirement timing influence the plans and expectations of individual workers.

Hypothesis 5: Older employees who work in organizations where working beyond the eligible age for early retirement is an exception will have lower (planned) retirement ages

A particularly relevant aspect of this normative context are the opinions and attitudes held by older workers' supervisors, who operate as links between organizational goals and the work environment. With the deinstitutionalization of retirement, variation in workplace support for working longer may become an increasingly important aspect of older workers' opportunity structure. Although supervisors may not always have a final say in older workers' retirement, their attitudes may be influential in the decision-making process (Armstrong-Stassen 1994, Vecchio 1993). Lack of managerial support can push older workers into premature and involuntary retirement (Van Solinge and Henkens, 2007). Indirectly, managers' attitudes towards older workers' employment can determine a work environment that either supports prolonged employment or channels workers into retirement.

Hypothesis 6: Older workers who have the feeling that their direct supervisor supports postponement of retirement will have higher actual or planned retirement ages

\section{Method}

\section{Data}

To answer the research questions this study used data from the NIDI Work and Retirement Panel. This is a multi-actor panel study, where older workers and their spouses have been 
followed for a period of ten years. The first wave of this longitudinal study was carried out in 2001. In three large Dutch multinational companies in the private sector (Unilever, IBM, VendexKBB), and in the public sector (Civil service), data were collected in collaboration with the HRM departments. The companies provided the random sample as well as financial background information (such as salary, replacement rate). The mailing was carried out by the companies, under supervision of the researchers. A random sample of employees aged 50 years and over working in the different operating companies of these multinationals (for the Civil service: different Ministries) received an envelope with the company's logo, including a questionnaire for themselves and a separate questionnaire for their married or unmarried partner, if present. The questionnaire included questions with respect to the older worker's financial, work, health and family situation, as well as their work-retirement plans. The data show a large variability with respect to different occupational settings and individual characteristics. The mail questionnaire was sent to 3,899 older workers; in total 2,403 questionnaires were completed (response rate 62\%). In 2006 a follow-up survey was conducted (Wave 2), in which all surviving Wave 1 participants were re-surveyed, once again by mail questionnaire. The Wave 2 survey asked respondents about changes in employment status, including retirement and retirement plans and behaviour, since Wave 1 . There was some attrition due to company takeovers $(N=$ 116), mortality $(N=44)$, and untraceable participants $(N=4)$. A total of 2,239 questionnaires were mailed out, of which 1,678 were returned providing complete or virtually complete data (response rate 75\%). In 2011, all surviving respondents have been re-interviewed, again by way of a mail questionnaire. There was some attrition due to mortality $(N=39)$, and untraceable participants $(N=3)$. A total of 1,636 questionnaires were sent to surviving Wave 2 participants; 1,276 surveys were returned, providing complete or virtually complete data (response rate $78 \%$ ). 
The Wave 3 survey asked respondents about changes in employment status, including retirement since Wave 2. Information regarding events and behaviour between wave 1, 2 and 3 are collected using the anchored retrospective approach (Bumpass and Raley, 2006).

For this particular study, we examined a subset of respondents who were in a career job at the time of the first interview and who participated in at least two of the three study waves undertaken in 2006 and 2011. Of the total potential sample of 1,461, we excluded respondents who did not answer any of the retirement intention $(N=3)$ or retirement behaviour $(N=11)$. This resulted in an analytical sample of 1.458/1.450 individuals. Item non-response was low (on average less than 3\%). Missing data were imputed using the multiple imputation option in Stata.

Age, gender as well as mortality information was available from the administrative records of each of the participating companies. ${ }^{\text {ii }}$ Sensitivity analysis revealed limited selective nonresponse. Neither age, nor mortality (which can be considered as a proxy for health status) predicted participation in Wave 1; there were no significant differences in non-response between the companies. Male older workers were somewhat more likely to participate in Wave 1 .Wave 2 participation was not related with gender and mortality between Wave 2 and 3, but younger respondents and employees that worked for the company that experienced many take overs between 2001 and 2006 were somewhat less likely to participate in the first follow up. Wave 3 participation was only related to age, in the sense that older participants were somewhat less likely to participate.

\section{Measures}


In the first wave of the study older employees were asked about their retirement intentions. Participants were asked "At what age do you plan to stop working?" (continuous variable). In the follow-ups participants were asked whether they had retired between survey waves. Individuals who responded affirmatively were then asked in what year and month. On the basis of this information the actual timing of retirement was determined. The time span between turning 50 and taking mandatory or early retirement (in years) was used as the dependent measure. Participants who had not retired between Wave 1 and Wave 3, or exit from the study were treated as right-censored. Table 1 presents means, standard deviations, coding algorithms, and the wording of the survey questions for the independent variables, as well as the psychometric properties of the scales.

Table 1 about here

\section{Statistical analysis}

Linear regression models were estimated to test the links between conditions at work and retirement intentions. The hypotheses regarding actual retirement timing were tested using Cox proportional hazards regression models. In our study older workers were sampled through their employers, hence observations may not be independent. In order to control for this design effect we adjusted for clustering at the company level as well as the branch level, using a stratified multiple stage design (STATA 2005: svy set). Without controlling for design effects, it is likely that biased standard errors would be produced. In the Cox model the stratification method was applied, which implies that for every organization a different unspecified baseline hazard 
function was allowed, while the coefficients of the other covariates were assumed to be constant across the organizations (Blossfeld and Rohwer 1995).

\section{Results}

The older workers in the panel had a clear preference for taking early retirement. Average planned retirement age at baseline was 60.2 years. Only a small minority planned to remain working until mandatory retirement age (65 years). 85 per cent of workers retired between 2001 and 2011. The results of the multivariate linear regression analyses and the Cox proportional hazards regression analyses to explain retirement intentions and actual retirement timing of older workers are presented in Table 2.

Table 2 about here

Retirement intentions - Column 2 in Table 2 provides the results for the linear regression model explaining retirement intentions, i.e. planned retirement age. The central explanatory variables of interest are job characteristics, organizational policies, and workplace norms and attitudes.

With regard to work/job characteristics we assumed that demanding job characteristics will be associated with a lower planned retirement age (hypothesis 1a), and that rewarding job characteristics will have the opposite effect (hypothesis 1b). The results of the analyses support these hypotheses to a some extent. Older workers who experience higher levels of challenge in their career jobs were less inclined to retire early. Among the demanding job characteristics in our model only perceived job pressure showed a significant relationship with planned retirement age. As older workers experience more job pressure, they plan to retire earlier. We did not find 
support for our hypothesis that demanding work and irregular working hours are related to retirement intentions.

We examined two dimensions of the organizational context: organizational HR policies for older workers and the organization's normative climate regarding retirement. We hypothesized that the organizational HR instruments considered (phased retirement, working times/workplace flexibility and training) would have a positive effect on older workers' retirement intentions in the sense that those who have access to this type of arrangements will be more inclined to retire later. Results in this respect are ambiguous though. We did find an statistically significant association with phased retirement, albeit in the opposite direction (hypothesis 4). Older workers who participated in a phased retirement arrangement at baseline (2001) had lower planned retirement ages. Our results do not provide evidence that training opportunities (hypothesis 2) and time/workplace flexibility (hypothesis 3) and are associated with later planned retirement.

We examined the impact of the organization's normative climate regarding retirement along two lines: older workers' perception of the organization's customs and practices regarding retirement timing, and supervisors' support for extending working life. We hypothesized that workplace norms and supervisors' attitudes toward older workers and retirement have an impact on retirement plans. Our results show a strong positive association between the organizational retirement culture and retirement intentions. Older workers in organizations where early exit is commonplace are themselves much more inclined to retire early as well (hypothesis 5). In addition, and in line with our expectations, supervisor support for prolonged labour force participation is positively associated with planned retirement age. Older workers with strong perceived managerial support for them to remain in their jobs intend to retire later (hypothesis 6). 
Some nuancing is in order here though: only 9 per cent of older workers perceived their supervisor's attitude with regard to working longer as particularly positive, the majority experienced indifference.

Personal resources served as control variables in our analysis. Results are consistent with earlier findings and stress the importance of social (partner) and economic resources (wealth) and health with regard to retirement planning. Access to financial resources in terms of accumulated wealth and higher expected retirement income (replacement rate) are associated with lower planned retirement ages. Workers in good health are more likely to report higher intended retirement ages, whereas older workers who do not have a partner are more inclined to delay retirement than older workers with a partner. This is irrespective of partner's labour force status: retirement intentions of older workers in dual earner couples did not significantly differ from that of older workers with a non-working spouse.

Retirement timing - Column 3 in Table 2 presents the results of a Cox regression model, with timing of retirement as the dependent variable. The presented figures are hazard rates. For example, a hazard ratio of 0.942 for perceived growth opportunities indicates that, other factors kept constant, an increase of one entity on the scale for growth reduces the chances of retirement by 5.8 per cent (1-0.942). A hazard ratio of 1.044 for wealth indicates that the chances of retirement increased by 4.4 per cent for every higher wealth class.

When we compare the results for pension behaviour with the results discussed earlier for pension intention, we witness several similarities but also remarkable differences. With respect to the primary explanatory variables, we establish that many of the factors that predicted retirement intentions do not appear to have an effect on actual timing of retirement. The most 
striking result is the small impact of job characteristics on actual retirement behaviour (hypothese1a-b). Whereas high job pressure and limited job challenge were associated with lower planned retirement age, we do not find effects for actual retirement age. In the retirement behaviour model, the only job characteristic that was significantly related to retirement timing is growth opportunities. Older adults who -at baseline- perceived more potential for growth in their organizations turned out to retire later. None of the three examined HR instruments had an effect on retirement timing (hypotheses 2-3). Phased retirement, which was associated with exit intentions, does not seem to predict actual retirement timing. Organizations' normative climate clearly plays a role in explaining actual retirement timing. Lack of managerial support for remaining in the workforce is associated with earlier retirement (hypothesis 6). No significant association was found for organizations' workplace norms regarding retirement (hypothesis 5). Older workers in organizations where remaining in the workforce up to age 65 is more exceptional do not retire earlier than workers in organizations where remaining in the workforce beyond early retirement age was more common. The findings confirm the impact of economic and social resources and health on actual retirement timing. The chances of an older worker retiring in the survey period are smaller for older workers in good health and for those with a partner. Wealth has the opposite effect, indicating that it may be partly used to facilitate early retirement.

Counter factional analyses - Employers are supposed to play a key role in the implementation of strategies to encourage older workers to remain in the workforce. In order to gain insight into the potential benefits of a supportive organizational climate for older workers, we carried out a simple scenario analysis that examined the effects of an organizational context supporting 
working longer. Table 3 sketches the estimated delay in the planned retirement age in a such a context. The planned retirement age is estimated on the basis of the regression model presented in Table 2. Model calculation shows that explicit supervisor support for continued labour force participation results in an increased planned retirement age by approximately 0.6 years. Coworkers who serve as an example have an effect too — albeit smaller. The table further shows that attractive conditions at work, in terms of challenging work and a low job pressure, may produce a delay in retirement of approximately half a year. In an extreme scenario where all stimuli are maximal, we find a delay of more than 2 years.

\section{Table 3 here}

Additional analysis (Table 4) comparing older employees' retirement intentions and behavior discloses a substantial discrepancy between stated and revealed preferences. The data suggest that there is a huge tendency to advance the moment of retirement: on average, older employees retired almost one year earlier than originally intended. This partly reflects the socio-economic climate in the Netherlands during the survey period. In the period of observation of our study many organizations offered early retirement programs that were designed in such a way that leaving the labour force at an early retirement age was an offer employees could not refuse. An important observation is that more than one quarter of retired older workers indicated that their exit was not entirely voluntary. Pressure put on them by their employer and/or colleagues was the reason indicated most often. 
Table 4 here

\section{Conclusion}

Understanding the forces that encourage or discourage older workers to remain employed is of eminent importance for governments and organizations dealing with an aging workforce. We examined work influences on both retirement intentions and actual retirement behaviour, using a 10-year follow-up study among 1,460 older employees in the Netherlands aged 50-59 at baseline. Our study suggests that older workers are very sensitive to the social approval earned from their co-workers and supervisor when they intend to work longer. A social climate that supports working up to a higher age seems to be an important requisite for reducing the attractiveness of the early retirement option. Retirement intentions — formed in the years prior to retirement — are strongly shaped by workplace norms and supervisors' attitudes in this respect. A social climate supporting the extension of working lives is however not self-evident. Although recent research reveals a growing awareness of the challenges of an aging society for labour organizations, employers seem to hold a double standard toward increasing the number of older workers and postponing retirement (Conen, Henkens and Schippers 2011). While agreeing that working longer may well become necessary in the future, employers still do not think it will apply to their own organizations. The fact that those older workers who live together with a partner or spouse prefer earlier retirement ages underscores the importance of social stimuli in the retirement process.

In this article we also examined whether popular age-related policy instruments, in particular phased retirement, have an impact on retirement decisions. We found that individuals 
who make use of phased retirement before they are eligible for full-time retirement prefer to retire earlier than individuals who do not make use of these arrangements. As such, our results provide additional evidence for earlier findings of Ghent et al. (2001), who showed that phased retirement arrangements promote rather than delay retirement. Several explanations could be explored here. One reason may be that phased retirement affects the work-leisure balance. Older workers acclimatize to a life where work is no longer in the lead. Positive experiences with leisure life may affect the retirement decision-making process, hence phased retirement may mark the start of the retirement adjustment process. The most obvious reason though may be that phased retirement arrangements are particularly popular among older workers with a preference for early retirement. In the absence of eligibility for full-time retirement, these older workers may use phased retirement to reduce their working hours.

Besides the social climate and the policy context within the organization, our study provides further empirical evidence that unfavourable job characteristics increase the propensity to retire early, whereas favourable job characteristics have the opposite effect. Challenging work in a context that does not overload older workers' mental capacity is an important factor for workers in delaying retirement plans. Surprisingly, we did not find an association between physically demanding (heavy) work and preferences for early retirement.

The large-scale panel study on retirement reported in this article also has limitations. First, although the sample does contain substantial variation in terms of important individuallevel and organizational variables, the data are not nationally representative and may not be entirely generalizable to the Dutch population as a whole. A second point that warrants attention concerns some of the measurement instruments that have been used. Several instruments are based on a limited number of items, which reduces the reliability of the scales. Further, the 
number of HR instruments considered was also restricted. We examined the impact of several popular human resource instruments on extending working life. The relevant HRM instrumentation is however much broader, as it also includes policies on wellness, health and employability. Future studies on the organizational influence on retirement may include a wider range of organizational policy instruments, such as mobility, demotion and health prevention.

We also recommend that future studies collect additional objective information on work and organizational characteristics. The subjective appraisal by respondents about aspects like their work being "physically heavy" does not necessarily run parallel with the way an ergonomist would assess a workload. To what extent more objective measures will lead to other outcomes is an interesting question for follow-up studies.

The success of policies on working longer is dependent on many factors and actors. The retirement decisions of older workers are to a large extent shaped by the their financial position and the possibilities and uncertainties of their pension schemes. Whether people will work longer, and how much longer, will also depend on the demand side of the labour market. Employers may or may not create opportunities for career extension. Our research shows that at least in the recent past - employers have put the brakes on older employees' ambitions to continue working. This paper shows that in the period under study older workers have had much less influence on the timing of their retirement than generally presumed, and that the choice space with regard to prolonged labour force participation was often very limited. The results of this paper indicate that in order to delay retirement, policy initiatives cannot be reduced to altering financial restrictions surrounding retirement, but need to address the forces at the organizational level that channel workers out of employment. 


\section{References}

Adams, G. A. and Beehr, T. A. 1998. Turnover and retirement: a comparison of their similarities and differences. Personnel Psychology, 51, 3, 643-55.

Anderson, K. H., Burkhauser, R. V. and Quinn, J. F. 1986. Do retirement dreams come true? The effect of unanticipated events on retirement plans. Industrial and Labour Relations Review, 39, 4, 518-26.

Armstrong-Stassen, M. 1994. Coping with transition: A study of layoff survivors. Journal of Organizational Behavior, 15, 7, 597-621.

Armstrong Stassen, M. and Ursel, N. D. 2009. Perceived organizational support, career satisfaction, and the retention of older workers. Journal of Occupational and Organizational Psychology, 82, 1, 201-20.

Bakker, A. B. and Demerouti, E. 2007. The Job Demands-Resources model: State of the art. Journal of Managerial Psychology, 22, 3, 309-28.

Bal, P. M., De Jong, S. B., Jansen, G. W. and Bakker, A. B. 2011. Motivating Employees to Work beyond Retirement: A Multi-Level Study of the Role of I-deals and Unit Climate. Journal of Management Studies. 49, 2 , 306-31.

Becker, G. S. 1975. Human capital. A theoretical and empirical analysis, with special reference to education. National Bureau of Economic Research, New York.

Beehr, T. A. and Bennett, M. M. 2007. Examining retirement from a multi-level perspective. In Shultz, K. S. and Adams, G. A. (eds), Aging and Work in the 21st Century. Erlbaum, Lawrence Associates, Inc. , 277-302.

Blekesaune, M. and Solem, P. E. 2005. Working conditions and early retirement: A prospective study of retirement behavior. Research on Aging, 27, 1, 3-30.

Blossfeld, H. P. and Rohwer, G. 1995. Techniques of event history analysis. New approaches to causal analysis. Lawrence Erlbaum, Mahwah, NJ.

Bumpass, L. L. and Raley, R. K. 2006. Measuring Divorce and Separation: Issues, and Comparability of Estimates Across Data Sources. In Hofferth, S.L. and Casper, L.M. (Eds) Measurement Issues in Family Research. Mahwah, NJ: Laurence Erlbaum Associates. 125-43.

Conen, W. S., Henkens, K. and Schippers, J. J. 2011. Are employers changing their behavior toward older workers? An analysis of employers' surveys 2000-2009. Journal of Aging \& Social Policy, 23, 2, 1-18.

Conen, W., Van Dalen, H. P. and Henkens, K. 2009. Werkgevers worstelen met verhoging pensioenleeftijd. Demos, bulletin over bevolking en samenleving, 25, 8, 1-4.

Demerouti, E., Bakker, A. B., Nachreiner, F. and Schaufeli, W. B. 2001. The job demands-resources model of burnout. Journal of Applied Psychology, 86, 3, 499-512.

Estryn-Behar, M., Van der Heijden, B. I. J. M., Fry, C. and Hasselhorn, H. M. 2010. Longitudinal analysis of personal and work-related factors associated with turnover among nurses. Nursing research, 59, 3, 166-77.

Feldman, D. C. and Beehr, T. A. 2011. A three-phase model of retirement. American Psychologist, 66, 3, $193-203$.

Ghent, L. S., Allen, S. G. and Clark, R. L. 2001. The Impact of a New Phased Retirement Option on Faculty Retirement Decisions. Research on Aging, 23, 6, 671-93.

Greller, M. M. and Stroh, L. K. 2003. Extending working lives: Are current approaches tools or talismans? In Adams, G. A. and Beehr, T. A. (eds), Retirement. Reasons, Processes and Results. Springer, New York, 115-35. 
Gruber, J. and Wise, D. 2004. Social Security Programs and Retirement Around the World. NBER. The University of Chicago Press, Chicago and London.

Gustman, A. L. and Steinmeier, T. 2009. How Changes in Social Security Affect Recent Retirement Trends. Research on Aging, 31, 2, 261-90.

Hedge, J. W., Borman, W. C. and Lammlein, S. E. 2006. The aging workforce: Realities, myths and impliations for organisations. American Psychological Association, Washington DC.

Henkens, K. and Tazelaar, F. 1997. Explaining retirement decisions of civil servants in the Netherlands. Research on Aging, 19, 2, 139-73.

Henkens, K. 1999. Retirement intentions and spousal support: A multi-actor approach. Journal of Gerontology: Social Sciences, 54B, 2, S63-74.

Henkens, K. and Van Solinge, H. 2002. Spousal influence on the decision to retire. International Journal of Sociology, 32, 2, 55-73.

Henkens, K. and Leenders, M. 2010. Burnout and older workers' intentions to retire. International Journal of Manpower, 31, 3, 306-21.

Herrbach, O., Mignonac, K., Vandenberghe, C. and Negrini, A. 2009. Perceived HRM practices, organizational commitment, and voluntary early retirement among late-career managers. Human Resource Management, 48, 6, $895-915$.

Hutchens, R. and Grace-Martin, K. 2006. Employer willingness to permit phased retirement: Why are some more willing than others? Industrial \& Labour Relations Review, 59, 4, 525-46.

Kubicek, B., Korunka, C., Hoonakker, P. and Raymo, J. M. 2010. Work and Family Characteristics as Predictors of Early Retirement in Married Men and Women. Research on Aging, 32, 4, 467-98.

Lawrence, B. S. 1996. Organizational Age Norms: Why Is It So Hard To Know One When You See One? The Gerontologist, 36, 2, 209-20.

Leonesio, M. V. 1996. The economics of retirement: a nontechnical guide. Social Security Bulletin, 59, 4, 29-50.

McCann, R. and Giles, H. 2003. Ageism and the workplace. A communication perspective. In Nelson, T. D. (ed.), Ageism, stereotyping and prejudice against older persons. MIT Press, Cambridge MA, 163-99.

Moen, P. 1996. A life course perspective on retirement, gender and well-being. Journal of Occupational Health Psychology, 1, 1, 131-44.

Patrickson, M. 2003. Human resource management and the ageing workforce. In Weisner, R. and Millet, B. (eds), Human resource management: Challenges and future directions. Wiley, Brisbane, 33-43.

Phillipson, C. 2004. Work and retirement transitions: Changing sociological and social policy contexts. Social Policy and Society, 3, 2, 155-162.

Potocnik, K., Tordera, N. and Peiró, J. M. 2009. The Role of Human Resource Practices and Group Norms in the Retirement Process. European Psychologist, 14, 3, 193-206.

Prothero, J. and Beach, L. R. 1984. Retirement decisions: Expectations, intention and action. Journal of Applied Social Psychology, 14, 2, 162-74. 
Schreurs, B., Van Emmerik, H., De Cuyper, N., Notelaers, G. and De Witte, H. 2010. Job demands-resources and early retirement intention: Differences between blue- and white-collar workers. Economic and Industrial Democracy, 32, 1, 47-68.

Settersten, R. A. 1998. Time, age, and the transition to retirement: New evidence on life course flexibility? International Journal of Aging and Human Development, 47, 3, 177-203.

Settersten, R. A. and Hagestad, G. O. 1996. What the latest? II. Cultural age deadlines for educational and work transitions. The Gerontologist, 36, 5, 602-613.

Shultz, K. S. and Wang, M. 2011. Psychological perspectives on the changing nature of retirement. American Psychologist, 66, 3, 170-79.

STATA. 2005. Stata Reference Manual, Release 9 (R-Z). Stata Press, Texas.

Szinovacz, M. E. 2003. Contexts and pathways: Retirement as institution, process, and experience. In Adams, G. A. and Beehr, T. A. (eds), Retirement. Reasons, Processes and Results. Springer, New York, 6-52.

Szinovacz, M. E. and Davey, A. 2005. Predictors of perceptions of involuntary retirement. The Gerontologist, 45, 1, 26-35.

Taylor, P. E., Brooke, L. and di Biase, T. 2010. European employer policies concerning career management and learning from a life-span perspective. In Naegele, G. (ed.), Soziale Lebenslauf Politik. VS Verlag, Wiesbaden, 47497.

Taylor, P. E. and Urwin, P. 2001. Age and participation in vocational education and training. Work, Employment \& Society, 15, 4, 763-79.

Taylor, P. E. and Walker, A. 1998. Employers and older workers. Attitudes and employment practices. Ageing \& Society, 18, 6, 641-58.

Thurow, L. C. 1975. Generational Inequality. Basic Books, New York.

Twenge, J. M., Campbell, S. M., Hoffman, B. J. and Lance, C. E. 2010. Generational differences in work values: Leisure and extrinsic values increasing, social and intrinsic values decreasing. Journal of Management, 36, 5, 1117 42.

Van Dam, K., Van der Vorst, J. D. M. and Van der Heijden, B. I. J. M. 2009. Employees' Intentions to Retire Early: A Case of Planned Behavior and Anticipated Work Conditions. Journal of Career Development, 35, 3, 265-89.

Van der Heijden, B. I. J. M., Schalk, R. and Van Veldhoven, M. J. P. M. 2008. Ageing and careers: European research on long-term career development and early retirement. Career Development International, 13, 2, 85-94.

Van Hoof, J. J. (ed.) 2002. Werk(en) moet leuk zijn. Arbeidswensen van Nederlanders. Van Gorcum/SMS, Assen.

Van Loo, J., De Grip, A. and Montziaan, R. 2006. Active aging bij overheid en onderwijs: vernieuwend omgaan met vergrijzing. In ROA/ABP, Maastricht.

Van Solinge, H. and Henkens, K. 2007. Involuntary retirement. The role of restrictive circumstances, timing and social embeddedness. Journal of Gerontology: Social Science, 62B, 5, 295-303.

Vecchio, R. P. 1993. The Impact of Differences in Subordinate and Supervisor Age on Attitudes and Performance. Psychology and Aging, 8, 1, 112-9.

Vickerstaff, S., John, B., Cox, J. and Keen, L. 2004. Happy Retirement? The impact of employers' policies and practices on the process of retirement. The Policy Press, Bristol. 
Table 1

Means $(M)$, standard deviations (SD), coding algorithms, wording of survey questions and psychometric properties of the independent variables $(N=1,458)$

\begin{tabular}{lcclc}
\hline & $M$ & SD & Coding Algorithm & Wording \\
& & & \\
\hline Gender & 0.75 & 0.4 & Dummy variable (1=male) \\
Age at baseline & 54.5 & 2.5 & Age (in years) at baseline \\
\hline
\end{tabular}

Household income (t1) $\quad 3.2 \quad 1.4 \quad$ Sum of worker's and partner's (if present) monthly income (in $\quad$ Workers' salary obtained from the Central Salary Administrations, patner's $€ / 1,000$ ), ranging from 0.73 to $11.84 \quad$ income asked in questionnaire

\begin{tabular}{|c|c|c|c|c|c|}
\hline Wealth (t1) & 4.4 & 1.6 & One item, ranging from $1(<5,000 €)$ to $7(>500,000 €)$ & $\begin{array}{l}\text { Wealth is a 7-category variable that measures the total value of household } \\
\text { property (including real estate and other assets, savings and other financial } \\
\text { wealth), net of debt. Categories range from } 1(<€ 500) \text { to } 7(\succ € 500,000) \text {. }\end{array}$ & $\mathrm{n} / \mathrm{a}$ \\
\hline $\begin{array}{l}\text { Expected retirement } \\
\text { income (replacement } \\
\text { rate) }\end{array}$ & 60.0 & 11.8 & Continuous variable ranging from 40 to 80 percent & $\begin{array}{l}\text { Net replacement rate is the net monthly salary received upon retirement at age } 60 \\
\text { (obtained from the Central Salary Administrations) }\end{array}$ & $\mathrm{n} / \mathrm{a}$ \\
\hline Health (t1) & 4.1 & 0.8 & 1 - item, ranging from $1=$ very poor to $5=$ very good health & $\begin{array}{l}\text { Question: "What is your general state of health?" (five answer categories: } 1=\text { very } \\
\text { poor to } 5=\text { very good) }\end{array}$ & \\
\hline Partner (t1) & & & $\begin{array}{l}\text { Dummy variable indicating whether or not participant has } \\
\text { partner/spouse (1=yes) }\end{array}$ & & \\
\hline $\begin{array}{l}\text { Physically demanding } \\
\text { work (t1) }\end{array}$ & 0.2 & 0.4 & Dummy variable, $1=$ yes (if one of the items is yes) & $\begin{array}{l}\text { Two questions: "Is your work physically demanding?" (yes/no); "Is your work } \\
\text { characterized by many inconveniences (e.g. smell, noise, draught)?" (yes/no) }\end{array}$ & $\mathrm{n} / \mathrm{a}$ \\
\hline Job Pressure (t1) & 2.9 & 0.9 & $\begin{array}{l}\text { 3-item scale (range } 0-5 \text { ). The } 5 \text {-point Likert-scaled responses } \\
\text { were summed and divided by } 3 \text {, where higher values represent } \\
\text { greater pressure. }\end{array}$ & $\begin{array}{l}\text { Items: "My job pressure is so great that it creates tensions"; "At times there is so } \\
\text { much work to be done that I'm unable to do everything"; "I often have to do my } \\
\text { utmost to perform well" ( } 5 \text { answer categories: } 1=\text { completely agree, and } 5= \\
\text { completely disagree, reversed coding). }\end{array}$ & Alpha $=075$ \\
\hline $\begin{array}{l}\text { Irregular working } \\
\text { hours }(\mathrm{t} 1)\end{array}$ & 0.18 & 0.4 & Dummy variable, $1=y e s$ (if one of the items is yes) & $\begin{array}{l}\text { Two questions: "Do you do shift work?" (yes/no); “Do you (regularly) work } \\
\text { during the evening or at night?" (yes/no) }\end{array}$ & $\mathrm{n} / \mathrm{a}$ \\
\hline
\end{tabular}




\begin{tabular}{|c|c|c|c|c|c|}
\hline & $M$ & $S D$ & Coding Algorithm & Wording & $\begin{array}{l}\text { Psychometric } \\
\text { Properties }\end{array}$ \\
\hline Job challenge (t1) & 5.8 & 2.2 & $\begin{array}{l}\text { 3-item scale (range } 0-10 \text { ). Responses to [1] and the 5-point } \\
\text { Likert-scaled statements [2] and [3] were summed and } \\
\text { transformed into a } 0-10 \text { range, as they were with job pressure, } \\
\text { where higher values represent greater job challenge. }\end{array}$ & $\begin{array}{l}\text { Items: [1] "My work is characterized by many challenging tasks" (yes/no); [2] } \\
\text { "The work I am doing is not very challenging"; [3] "The work I am doing has } \\
\text { become more and more boring and routine" ( } 5 \text { answer categories: } 1 \text { = completely } \\
\text { agree and } 5=\text { completely disagree, reversed coding if appropriate). }\end{array}$ & Alpha $=0.76$ \\
\hline $\begin{array}{l}\text { Growth opportunities } \\
\text { (t1) }\end{array}$ & 2.4 & 0.8 & $\begin{array}{l}\text { 3-item scale (range 1-5). The 5-point Likert-scaled responses } \\
\text { were first summed and divided by } 3 \text {, higher values indicate } \\
\text { more opportunities for growth. }\end{array}$ & $\begin{array}{l}\text { Items: "My work offers ample opportunities for promotion"; "My job now offers } \\
\text { few opportunities for growth"; "I have more or less reached a dead end in my } \\
\text { work" ( } 5 \text { answer categories: } 1 \text { = completely agree and } 5=\text { completely disagree, } \\
\text { reversed coding if appropriate). }\end{array}$ & Alpha $=0.63$ \\
\hline $\begin{array}{l}\text { Perceived schooling } \\
\text { opportunities }\end{array}$ & 3.7 & 0.9 & $\begin{array}{l}\text { One item (range 1-5), higher scores indicate more training } \\
\text { opportunities. }\end{array}$ & $\begin{array}{l}\text { Item: "If you want additional training/schooling in my company, this can always } \\
\text { be arranged" ( } 5 \text { answer categories: } 1=\text { completely agree and } 5=\text { completely } \\
\text { disagree, reversed coding). }\end{array}$ & $\mathrm{n} / \mathrm{a}$ \\
\hline $\begin{array}{l}\text { Working times/ } \\
\text { workplace flexibility }\end{array}$ & 6.7 & 2.0 & $\begin{array}{l}\text { 4-item scale (range } 0-10 \text { ). Weighted responses to [1], [2] and } \\
\text { [3] and the 5-point Likert-scaled statements [4 were combined, } \\
\text { with appropriate reverse-coding, and transformed as they were } \\
\text { with job pressure, so that higher values indicate greater } \\
\text { flexibility }\end{array}$ & $\begin{array}{l}\text { Questions: "Are you able to start work later or leave earlier"; "Are you able to } \\
\text { work from home" (yes/no); "How flexible are you in terms of your work when } \\
\text { unexpected family circumstances arise (e.g. sick spouse or parent)?" ( } 5 \text { answer } \\
\text { categories: } 1=\text { very flexible, } 4=\text { not al all flexible, reverse coding); "If I want to } \\
\text { take a few days off, I have to arrange this well in advance" ( } 5 \text { answer categories: } 1 \\
\text { = completely agree and } 5=\text { completely disagree, reversed coding ). }\end{array}$ & Alpha $=0.63$ \\
\hline Phased retirement & 0.12 & 0.3 & Dummy variable (1=yes) & $\begin{array}{l}\text { Phased retirement is a dummy variable indicating whether or not an individual } \\
\text { was involved in a phased or partial retirement program at Wave } 1 .\end{array}$ & $\mathrm{n} / \mathrm{a}$ \\
\hline Peer retirement & 3.2 & 1.0 & One item (range 1-5) & $\begin{array}{l}\text { Item: "All my colleagues are retiring early". The } 5 \text {-point scale for this item ranged } \\
\text { from " } 1 \text { " fully agree to " } 5 \text { " totally disagree. Scores were reversed so that a high } \\
\text { score indicated a more visible early exit organizational culture. }\end{array}$ & $\mathrm{n} / \mathrm{a}$ \\
\hline Supervisor support & 3.5 & 0.7 & $\begin{array}{l}\text { 2-item scale (range 1-5). Responses to [1] and [2] were } \\
\text { combined, with appropriate reverse-coding, and transformed } \\
\text { as they were with job pressure, so that higher values indicate } \\
\text { more supervisor support. }\end{array}$ & $\begin{array}{l}\text { Questions:[1] "How would your supervisor react if you continued working until } \\
\text { you were 65?" (answer categories ranging from "11" "My supervisor would not be } \\
\text { happy about that at all" to "5" "My supervisor would be very much in favor of } \\
\text { it"); [2] "I don't think my supervisor would mind at all if I continued working } \\
\text { until the age of } 65 \text { ". }\end{array}$ & Alpha $=0.69$ \\
\hline
\end{tabular}


Table 2. Models of retirement intentions and timing, coefficients and standard errors

\begin{tabular}{|c|c|c|c|c|c|c|}
\hline & \multicolumn{3}{|c|}{$\begin{array}{l}\text { Retirement intention } \\
\text { Linear regression model }\end{array}$} & \multicolumn{3}{|c|}{$\begin{array}{l}\text { Retirement timing } \\
\text { Cox } \mathrm{PH} \text { model }\end{array}$} \\
\hline & Coef. & & SE & Hazard Rate & & SE \\
\hline Intercept & 41.10 & & & & & \\
\hline Age at baseline & 0.436 & $* *$ & 0.05 & & & \\
\hline Gender $($ male $=1)$ & 0.023 & & 0.13 & 0.878 & & 0.12 \\
\hline \multicolumn{7}{|l|}{ Job Characteristics } \\
\hline \multicolumn{7}{|l|}{ Demanding characteristics } \\
\hline Physically demanding work & 0.138 & & 0.14 & 1.115 & & 0.07 \\
\hline Job pressure & -0.221 & $* *$ & 0.07 & 1.027 & & 0.03 \\
\hline Irregular working hours & -0.176 & & 0.17 & 0.922 & & 0.05 \\
\hline \multicolumn{7}{|l|}{ Rewarding characteristics } \\
\hline Job challenge & 0.138 & $* *$ & 0.03 & 0.977 & & 0.01 \\
\hline Growth opportunities & 0.122 & & 0.08 & 0.943 & * & 0.03 \\
\hline \multicolumn{7}{|l|}{ Organizational characteristics } \\
\hline \multicolumn{7}{|l|}{ Policy context } \\
\hline Perceived schooling opportunities & -0.021 & & 0.06 & 1.024 & & 0.04 \\
\hline Working times/workplace flexibility & -0.033 & & 0.03 & 0.997 & & 0.02 \\
\hline Phased retirement & -0.536 & $* *$ & 0.15 & 1.076 & & 0.07 \\
\hline \multicolumn{7}{|l|}{ Normative context } \\
\hline Peer retirement & -0.215 & $* *$ & 0.06 & 1.032 & & 0.03 \\
\hline Supervisor support for working longer & 0.419 & $* *$ & 0.08 & 0.838 & $* *$ & 0.03 \\
\hline \multicolumn{7}{|l|}{ Resources } \\
\hline Household income & -0.034 & & 0.03 & 0.986 & & 0.02 \\
\hline Wealth & -0.235 & $* *$ & 0.05 & 1.044 & $*$ & 0.02 \\
\hline Expected retirement income (replacement rate) & -0.092 & $* *$ & 0.01 & 1.022 & $* *$ & 0.01 \\
\hline Health & 0.185 & $* *$ & 0.05 & 0.911 & $* *$ & 0.02 \\
\hline \multicolumn{7}{|l|}{ Partner's work status } \\
\hline No partner at baseline & 0.552 & $*$ & 0.19 & 0.853 & $*$ & 0.06 \\
\hline Partner not in workforce at baseline & --- & & & --- & & \\
\hline Partner in workforce at baseline & 0.108 & & 0.14 & 0.924 & & 0.05 \\
\hline $\mathrm{N}$ & 1,458 & & & 1,450 & & \\
\hline $\mathrm{R}^{2}$ & 0.30 & & & & & \\
\hline $\mathrm{F}$ & 38.56 & $* *$ & & & & \\
\hline Wald Chi-square & & & & 172.46 & $* *$ & \\
\hline
\end{tabular}


Note $1: * \mathrm{p}<0.05 ; * * \mathrm{p}<0.01$.

Note 2: In all models "organization" is controlled for, either by using a cluster approach (intention models) or by stratifying by organization and branch within organization (actual timing models).

Note 3: Duration between age 50 and taking mandatory or early retirement (in years). Participants who had not taken early retirement between waves 1 and 2 were treated as right-censored. 
Table3. Potential benefits on intended retirement age of a supportive organizational climate for older workers

Positive Scenario

Gain in labor years

Normative context

Supervisor explicitly supports working longer $\quad+0.6$

Co-workers all remain working until retirement age $\quad+0.5$

Job characteristics

Very challenging work

$+0.6$

Low job pressure

$+0.4$

Total effect

$+2.1$

Note: Average planned retirement age in the model is 60.2 years. 
Table 4. Additional descriptive results for retirement intentions and retirement behavior

\begin{tabular}{lcc}
\hline \hline & $\%$ & $\mathrm{~N}$ \\
\hline \hline Planned retirement age in 2001 (average) & 60.2 year & 1,458 \\
Proportion that took mandatory/early retirement between 2001 and 2006 & 85 & 1,237 \\
Proportion that indicated retirement was partly involuntary & & \\
(as \% of total number of retired persons) & 29 & 364 \\
Reasons retirement was involuntary* & & \\
$\quad$ - Pressure from employer/co-workers & 68 & 248 \\
$\quad-$ Worker's health & 26 & 96 \\
- Partner's health & 6 & 25
\end{tabular}

Retirement behavior compared to retirement plans in 2001

$\begin{array}{ll}\text { Stopped earlier than planned } & 51\end{array}$

$\begin{array}{ll}\text { Stopped at planned retirement age } & 17\end{array}$

Stopped later than planned/still active and older than planned retirement age

Still active and younger than planned retirement age

6

86

Total

100

Discrepancy between planned and actual retirement age for those who retired between 2001 and 2006
- All retirements
-0.96 years
- Retired involuntarily due to organizational pressure
-1.55 years

* More than one reason allowed, as a result totals may not count to 100. 
${ }^{\mathrm{i}}$ The percentage of preretirement salary that is available to a worker in retirement.

ii Except for the 116 employees whose company had been taken over. 